\title{
Literature and Politics: A Semantic Analysis of Wale Okediran's Tenants of the House
}

\author{
Juliet Nkane Ekpang \\ Department of English \& Literary Studies, University of Calabar (Nigeria) \\ julietekpang@yahoo.com
}

\author{
Doi:10.5901/mjss.2014.v5n23p2458
}

\section{Abstract}

Published in 2009, Wale Okediran's Tenants of the House is a fictional prose that chronicles the Nigerian political system from the perspective of a member of the Federal House of Representatives. The novel highlights the prevailing circumstances surrounding the different impeachment bids which colour Nigerian politics and gives an insider view of the methods of operation of members of the ruling class. This paper sets out to study the lexical choices and other linguistic devices used to portray the theme of the text. Samples of lexical items and expressions are selected, examined and analyzed for their morphological, syntactic and semantic peculiarities. This paper explores how literature has been exploited to reveal the direction, dynamics and possibilities of politics in Nigeria as it pertains to certain linguistic, religious, economic, cultural and political peculiarities of the people. The framework for the study is drawn from lexical semantics as well as sociolinguistic approach to language study.

\section{Introduction}

Tenants of the house is a fictional representation of the happenings in the House of Representatives, the second highest legislative council in Nigeria. The events chronicled took place between the years 2004 and 2007. These include the aborted impeachment move of the then Speaker of the House and subsequent attempts at a bogus constitutional amendment in order to extend the tenure of the executive arm of government.

Okediran develops several character portraits through which he establishes the strengths and weaknesses found in the legislative and executive arms of government in Nigeria. For instance, Chief Ambrose Oneya, the president, presents the picture of a power-drunk, manipulative and greedy fellow who is temperamental and psychopathic. Through the characters, Honourable Yaya and the Deputy Speaker of the House, the ruthlessness in politicking and the viability of the phrase "no permanent friends in politics" is delineated. The possibility of hope and a sane future for Nigerian politics if there is an educated majority in the legislature is not sustained as even the seemingly upright Honourable Samuel Bakure is not consistent in his morals.

It is probable that Okediran sees himself in the character of Honourable Bakure, an educated but naive member of the House as far as politics is concerned. However, Bakure soon matures and finds his voice and place in the process of things. He takes his stand against unjust bills and remains focused in the entrenchment of positive changes in the proceedings of the House. However, he is portrayed as an oppressor of some sort in the love triangle between him, a rural Fulani girl (Batejo) and her betrothed (Gidado). Honourable Bakure tries to use his wealth and sophistication to win the girl's hand in marriage although he knew she was already betrothed to Gidado whom he labels, "an illiterate povertystricken cowherd" (TOH, 288). The weigh appears to tilt in his favour when Gidado could not provide the required ten cows as "bride-price". But he was publicly disgraced when he could not endure the ceremonial flogging which suitors of Fulani maidens have to undergo.

In a review by Reuben Abati, the text is described as a "factional" work or historical fiction and a product of Okediran's three years experience as a member of the House of Representatives. It is an account of the role and contributions of members of the House of Representatives made in resolving the events that nearly rocked the polity of the nation. This study uses the lexico-semantics as well as sociolinguistic approach to examine Okediran's use of language.

\section{Theoretical Framework}

Semantics is concerned with meaning. There are many approaches to this study: one of which is the study of lexical items in a text. This approach is called lexical semantics. Every word has three major properties: the phonological, the 
syntactic and the semantic. Syntactically, words have syntagmatic and paradigmatic relationships which are meaning sensitive (Tomori; 1977). According to Saussure (quoted in Ndimele; 1997) syntagmatic relations are "those that lexical items enter into with other units with which they occur and which constitute their context." In other words, lexical items sometimes impose constraints on other lexical items they occur with. When this constraint is semantically motivated, Tomori refers to it as selectional restriction.

The rules of selectional restriction are intentionally violated in some literary works (Lyons; 1977) whereas in ordinary writing, subjects and objects must possess as one of their semantic features or sense components, the action inherent in the verbs. This is not so in creative works of art. The violation of this rule is made possible through the instrumentality of figurative devices that are alternate in nature (Udofot; 1998) such as metaphors and similes. Words also have semantic features which are useful in studying their meaning. This is done through an approach known as componential analysis. The earliest proponent of this concept is L. Hjelmslev (Ndimele; 1997). It is through examining semantic features that one can deduce certain relationships between words such as antonymy, synonymy, polysemy and homonymy. This approach is however only useful in the study of content words.

Content words form the largest number of words in a language because they are an open class of items. New words are added regularly to the repertoire of a language as occasioned by innovations, inventions, discoveries or sociopolitical, cultural and religious changes. For instance, words such as "soludomy" and "Neparization" are relatively new linguistic coinages in Nigeria occasioned by changes in policies in the banking industry (Soludo being an erstwhile governor of the Nigerian Central Bank who initiated some changes) and NEPA being the name of the company that was in charge of electric power distribution at one time. The company was notorious for its poor supply of electric power, hence the coinage. Neologisms, code mixing, semantic shifts and semantic transfers also account for much of the lexical creativity found in the novel.

In this paper, the lexical items and sentences selected from the text are organized under the following sub-titles: metaphors, similes, code-mixing, pidgin and sub-standard English, the language of the legislative chamber, political terminologies and coinages.

\section{Textual Analysis}

\subsection{Metaphor and Simile}

The language of the novel spots several metaphors and similes which are devices of altered signification. These devices are used to make descriptions clearer through the comparison of an unfamiliar object with that which is relatively known (Ebam \& Nta: 2009). Some metaphors in Tenants of the House include: "Museum mind" (71); "Human wall" (122); "soldiers are mad dogs and policemen are hungry puppies" (88); "...the bearing of a man forced to eat eba without meat" (119); "my bed has become an arctic outpost fit only for penguins" (130) and "President Oneya is a fox..." (133). In a discussion between President Oneya and his liaison officer to the House of Representative, Senator Kayode Smollet, the president wanted to know what the man studied at the university. Smollet responded that he studied History. To establish the character of Chief Oneya as an under-educated incipient bi-lingual, Oneya equates the study of history with the study of ancient artifacts. This retort was occasioned by Senator Smollet's report on the opposition group in the House led by Honourable Wenike. The dissident group had agreed to meet at a hotel conference room where the mace they had stolen would be used as the instrument of authority to empower them to suspend all absent members and thereafter impeach the Speaker of the House. The President called the plan an unorthodox one. But, this does not stop the President from funding the impeachment move as it would be to his advantage.

Soldiers are referred to as 'mad dogs' and the police as 'hungry puppies' ( $p .88)$. Direct comparison is used here to vivify and question the actions of the Nigerian military during civil crisis. This picture of a deranged rabid dog that bites without provocation is drawn by Honourable Adeyi. His argument is that no matter how violence-free a civil demonstration appears, it is likely to result in bloodshed because of the temperament of Nigerian soldiers who shoot at civilians even without provocation. The police also are uncompromisingly loyal to the political class and to please the rulers can do anything, including hurting unarmed demonstrators in order to get monetary reward from those in power.

Honourable Adeyi uses this analogy to counter the Deputy Speaker's proposition that they should use a human wall to prevent Honourable Wenike's group from gaining entry into the legislative chambers. The protesters are to form a barricade (a wall) to deny the impeachment plotters entry into the legislative chamber, but this wall is to be formed by their bodies, hence the metaphor "human wall" (112). The writer thus points out the possible role the masses can play in fighting the ills of society thereby establishing the potency of mass struggle.

Another example, "...the bearing of a man forced to eat eba without meat" (119), is used to underscore the degree 
of discomfort experienced by Honourable Wenike when he realizes that his plans to impeach the speaker had failed. "Eba" is a staple food eaten across several geographical regions of Nigeria. It is eaten with soup. The soup is usually spiced with meat which gives it its taste. Naturally, eating eba without meat may make the meal less nutritious and most likely unpalatable. Anyone who eats eba this way does so not out of choice but because of unfavourable economic circumstances. It is to this scenario that Wenike's predicament is compared.

In "my bed had become an arctic outpost fit only for penguins" (130), Honourable Bature expresses the loneliness he feels at the end of each working day as he returns home to an empty house devoid of his wife and son. It is this need for companionship that drives him to try to build two relationships with the opposite sex in the novel. When he fails in both, he compares the lack of love in his life to the coldness of an arctic outpost where only penguins thrive.

Another metaphor is "President Oneya is a fox". A fox is believed to be both cunning and destructive. Honourable Bature however agrees that all politicians are flexible and to an extent unreliable. He is therefore wary of any close dealings with President Oneya. Bature believes that the President is quite capable of destroying even those he calls his friends. As he puts it, "...one moment he is kissing you, the next he is stabbing you in the back" (133).

Perhaps more mentally picturesque are the similes used in the text. The following are some examples: "The Dorchester was one of those new state of the art hotels that dotted the Abuja landscape like pimples on an adolescent's face (37). In 2004, when the events fictionalized in the text took place, Abuja was a young federal capital territory barely thirteen years old. The presence of pimples on the face of an adolescent is a mark of nascent maturity. The writer implies that the Dorchester hotel is quite impressive in size and so stands out in its neighbouring environment and that just as pimples signal maturity, the presence of hotels is a sign of the growth and development of Abuja.

In "...the smoke began to rise until the tobacco became well alight like the bellows at a blacksmith's" (4a). The writer compares Honourable Yaya's mood to the bellows in a smith's forge. At the critical moment, as Yaya ponders on ways to escape his proposed impeachment, the smoke he exhales from his pipe is likened to the smoke from the bellows at the point of metal smelting. Other examples of similes include: "I was like a rat facing a trap" (52), "... like a policeman signalling a car to stop" (88) and "the rumour of the prolongation plan thick in the air like harmattan in January..." (175). Sometimes both devices, metaphors and similes, are used side by side in a sentence. An example of this is, "... that power is a drug; some men are drawn to it like moths to a candle (184).

\subsection{Code-mixing}

Another characteristic of the language of the text is the use of code-mixing. According to Traugott and Pratt (1980), codemixing describes the alternating of codes of different languages or varieties of the same language within a sentence. It is common in bi-lingual and multilingual societies such as Nigeria. Bassey (2009) asserts that code-mixing is a tool "for character delineation, (and) is sometimes used as a form of political expression, a move either to resist some other power, or to gain power or to express solidarity" (88). It is in line with Bassey's views that code-mixing is used in the text. Nigeria, being a multi-lingual society, is expressly conscious of it multi-ethnic heritage in the political and social arenas. All appointments into federal offices and even federal elective positions are made within a policy known as Federal Character. By this policy, all appointive and elective positions are zoned to avoid the marginalization of some ethnicities as well as inter-ethnic clashes. This reality is taken into consideration in the text. The president is from the South-West, the Vice President from the North, the Senate President from the South-East while the Speaker of the House of Representatives is from the North.

Apart from the names of the characters, code- mixing is used as a form of establishing comradeship based on language. It is used in informal settings all through the text. It is also used for emphasis as most often what is said in one code is repeated in English. At other times, however, there are lexical items in other codes that are used without any interpretation in the text. Some of such words are "udah" (71), "agbada babariga" (211), "Sharo" (292), "Saida \& riga" (144). These words are borrowed from different mother tongues across the country. For example, "agbada" is a Yoruba word whereas "babariga" is Hausa and they are synonymous, both referring to large voluminous gowns worn by men. Such lexical items abound in the variety called Nigerian English. Examples of code switching are: "Kashe wa ni Laifi ne, amma yin haka a lokachin day a d ace siya san e! (5). This utterance means "To kill is a crime: to kill at the right time is politics. Another one, "... a siya sa ba abota har abada, sai dai akwai buka tar na abada" (10) means "There are no permanent friends in politics, only permanent interest; and "Nawa ya ba ka?" (64) means "How much did he [the speaker] give you?" These statements were made by Honourable Elizabeth Bello to Honourable Bature. The statements also underscore the cordial relationship between the two members. This different code stands out from the predominant language of the text and is used as an instrument of foregrounding. It highlights the message of the text that politics is a dirty game as well as the role money plays in the scheme of things. 
The personality and the level of education of a character influences the language variety which the author assigns him/her. Honourable Wenike and President Oneya speak pidgin and sub-standard English in most of their discourse in the text. The writer uses language variety to draw attention to the kind of political leaders Nigeria had. The language and actions of Oneya and Wenike are juxtaposed with the language and actions of the likes of Honourable Yaya and Bature.

Some examples of pidgin and substandard English in the text are: "Leave me bo..." (18); "Chei! Dem say anoder crowd dey for back entrance (10); "Which rotten control? Two million dollars down the drain and that yeye Yaya went on the NTA speaking fine grammar at a press conference ... in control my big toenail"(82); "You, you put sand in our garri and dust in our cornflakes..."(118). The last two examples depict a variety of Nigerian English which strives to parallel the educated variety of English used by characters such as the Deputy Speaker, Honourable Bature and Kalkulus. The educated variety can be better appreciated through the appropriate use of idiomatic expressions as in the examples below: "...the penny dropped with me" (96); ...that Mark was going under the knife (123); "I will pick their brains" (134); "Who has been laying it on thick for you?". (172) and "... not to rock the boat" (181).

It is however interesting to note that the language used in the legislative chambers is portrayed in the text as formal. A normal day sitting begins with the chant of "Mr speaker, Mr speaker!" from the Sergeant at Arms to usher in the Speaker. This is followed by a brief prayer and then the presentation of petitions in an orderly manner presided by the Speaker. Terms often used include "House rules" (19); point of order (21); invoke subsection... (22); establish a prime facie case of breach of privilege... (23).

Humour is also employed in the text. Below is a vivid example:

My name is Honourable Ahmed. I represent Jigawa central constituency. I wish to seek for an amendment in the last prayer of the motion: instead of members visiting China, they should go to space, since it was in space that the satellite disappeared. The only problem is how to get a visa to visit space... (225)

\subsection{Coinages}

This study would be incomplete without the examination of some political terminologies and coinages used to further advance the message of the text which is an exploration of the corruption and greed of the ruling class. These terminologies include: godfatherism (4), fertilizer of politics (8), Ghana-must-go bag" (39), operation kyarkeci (92), swagger (116), resource control (136), gigolo (207), kitchen cabinet, cocaine-fuelled performance (10) and cocaine-bright (117).

The word "Godfatherism" refers to the prevalence in the political arena of people who are elected into office not on merit but through the influence of some other political big-wigs. Most of the time, these heavy weights are the financial beneficiaries from the offices into which their protégés have been elected. Examples of this in the text are Honourable Elizabeth Bello who won her ticket through the influence of her father, a well known politician (3) and Honourable Lamidi Kasali who has a godfather in Oyo state as the excerpt below attests:

Hon. Lamidi Kasali; the tough godson of a tough godfather from Oyo state...whose one qualification for his parliament seat was his unalloyed loyalty to his crusty godfather, was a former chairman of the driver's and conductor's union. A real rough neck, Kasali was veteran of bare-knuckle fights in the streets of Ibadan (20).

Another term, "fertilizer of politics", on the other hand, occurs about six times in the text and refers to money given as bribe or a motivating factor to do the giver's bidding. The frequency of occurrence is an indicator of its centrality to the preoccupations in the novel. The writer appears to be calling for selfless service such as the one rendered by the Honourable Kalkulus led group who opposed and prevented the tenure elongation bill. In an argument, Honourable Adeyi reiterates that "patriotism is alien to the Nigerian soil." He concludes that, "All people want is money to eat" (88) and that no man will stand up to oppose what is wrong except such a person is financially motivated. Senator Smollet agrees with this view when he advises the president that giving bribe to legislatures is a strategy for political success. Below is an excerpt from his advice:

... hit them, hit them hard; give them what they dare not reject. Sir, we must remember it is a contest of wills and resources. It's a tug of war: naira for naira, dollar for dollar. Money it the name of the game... (2a)

Another example is:

When again, this plan failed, the ultimate bait of money was resorted to ... half a million US dollars per legislator! ... though the bank had closed for business that day, lawmakers were still trooping in for their share as late as midnight. 
This brings to mind the recent bribery scandal in Nigeria between Honourable Farouk Lawal and Mr Femi Otedola a business man. Farouk was member of the House of Representatives. The allegation is that the sum of 620 thousand dollars was exchanged for silence in a matter under investigation in the House. Farouk, who was the chairman of the committee in charge of the investigation, is presently being interrogated by the Economic and Financial Crimes Commission (EFCC) in Nigeria.

"Ghana-must go bags" is another expression used in the text to refer to large carrier bags. The bags connote bribery in Nigeria because they are purportedly used to convey such monies. Operation Kyarkeci, literarily means "operation wild dog". It is the name for the counter moves to forestall the president's sponsored impeachment plan in the House of Representatives. Another word, "swagger" in Nigerian context means 'style'. In "Wenike had lost his swagger" however, the writer means he had lost his confidence or boisterous style. He no longer had the mien of the man who was sure of his success.

Another term used in the text is "resource control". One of the main focuses of the writer of the text is the chronicling of different cultures in Nigeria. He does this by describing their traditional outfits. The term "resource control" is commonly used in Nigeria to refer to the traditional attire of the people of the Niger-Delta region. It comprises a pair of trousers, a long stylish shirt with gold/silver buttons, a bowler hat and a staff to match. In addition to this, the writer expresses beauty in diversity in his description of the array of colors in the legislative chambers during the public hearing for the bill for an act to establish a commission for pastoralists and agriculturalists in Nigeria. Below is an excerpt that illustrates this: "The assorted colourful dress of the Fulanis blending radiantly with the white galabiyas of the Hausa farmers and the dark suits of the officials from government agencies..." Through this exposition, the writer advocates the peaceful co-existence of the various ethnic groups in spite of their differences. He emphasizes the proposition that every culture has its uniqueness and beauty.

"Gigolo" is name for male prostitutes patronized by wealthy ladies in the Abuja metropolis while "kitchen cabinet" constitutes few top government officials- the President, the Vice President, the liaison officer to the legislative house, the Deputy Senate President and the Deputy Speaker of the House of Representatives. They are so named because although they cannot form the President's cabinet they are called upon to deliberate and proffer solutions to the President's dilemma at the threat of impeachment and subsequent prosecution.

"Cocaine-fuelled performance" and "cocaine-bright" are compound-word-coinages in the text. When Honourable Bature witnesses the Deputy Speaker ingesting drugs he is mesmerized. But this knowledge gives him an insight into the secret practices of some public figures. He refers to the charismatic speech of the Deputy Speaker as "cocaine-fuelled" and his countenance as "cocaine-bright". This speech highlights the hypocrisy of government officials. The Deputy Speaker publicly condemns drug abuse but is secretly a user of such substances (121).

\section{Conclusion}

The text Tenants of the House is rich in meaning and this paper is in no way exhaustive in identifying these meanings. However, the analysis of the selected lexemes and expressions reveal the density of figurative usage while other linguistic devices identified like code-mixing, pidgin and the substandard variety of Nigerian English, specialized language of the legislation, political jargons and coinages reveal the peculiarities of English language used in the Nigerian linguistic environment. These devices aid in character delineation as well as in unfolding the message of the text. The language in the novel reinforces the notion that Nigeria's multilingual and multicultural heritage is more of a blessing that a handicap. It also sounds a note of hope for the society's underdogs.

\section{References}

Bassey, V. (2009). Code-switching and code mixing as socio-ethnic affirmation in Nigerian home movies. Currents in African Literature and the English Language (CALEL) 86-97.

Ebam, P. O. \& Nta E. (2009). Metaphors in Joe Ushie's Lambs at the Shrine. Currents in African Literature and the English Language CALEL VI 32-46.

Lyons, J. (1977). Semantics. Cambridge: Cambridge University Press.

Ndimele, O. (1997) Semantics and the frontiers of communication. Port Harcourt: Uniport Press.

Okediran W. (2009) Tenants of the house. Ibadan: Nelson.

The Webster's dictionary of the English language. (2000). Washington DC: Lexicon Publication.

Tomori, S. H. O. (1977). The morphology and syntax of present-day English: An introduction. London: Heinemann.

Traugott, E. C. and Pratt, M. L. (1980). Linguistics for Students of Literature. New York: Harcourt Brace.

Udofot, I. (1998). English semantics. Uyo: Scholar Press. 